\title{
Predictors of school reintegration of black women who previously dropped out of school in the North West province of South Africa
}

\author{
Ayiga Natal ${ }^{1^{*}}$ and Mhele Karabo ${ }^{2}$ \\ ${ }^{1 *}$ Population Research and Training Unit, North West University, Mafikeng Campus Private bag \\ X2046 Mmabatho 2735, South Africa, Tel: 018389 2611, Email: Natal.Ayiga@nwu.ac.za; \\ nayiga1962@gmail.com. \\ ${ }^{2}$ Population Research and Training Unit, North West University, Mafikeng Campus Private bag \\ X2046 Mmabatho 2735, South Africa. Email: Mhele.Karabo@nwu.ac.za.
}

\begin{abstract}
Despite policies being in place, school re-entry of the girl child after school dropout continues to be low in sub-Saharan Africa. This paper estimated the school re-entry of girls who dropped out of school and identified the predictors affecting school re-entry. The paper used cross-sectional data on 306 black women who dropped out of school in the North West Province of South Africa and the logistic regression model to analyse the data. The result shows that only $28.1 \%$ of the women returned to school. School pregnancy, dropping out of school at I7-19 and 20 years of age, perceiving that neighbourhood peers were not in school and residing in rural neighbourhoods, significantly reduced school re-entry. We conclude that school re-entry after school dropped out is low in the North West province, which calls for programmes to address factors impeding school re-entry of the girl child.
\end{abstract}

Keywords: School re-entry; dropout; pregnancy; neighbourhoods; family structure

\section{Résumé}

Malgré les stratégies en place, le taux des réintégrations des jeunes filles à la rentrée scolaire reste encore faible en Afrique sub-saharienne. Cette étude a évalué la réintégration à l'école des filles qui avaient abandonné et a identifié aussi les facteurs prédictifs affectant leur réintégration à l'école dans la province du Nord-Ouest en Afrique du Sud. Dans cette étude les données transversales sur 306 femmes noires qui ont abandonné l'école dans la province du Nord-Ouest de l'Afrique du Sud et le modèle de régression logistique ont été utilisés pour analyser les données. Les résultats montrent que seulement $28,1 \%$ des femmes ont réintégré l'école. La grossesse a l'école, l'abandon scolaire à 17-19 et 20 ans, l'influence des amis des quartiers ayant abandonnés l'école auparavant et résidant dans les quartiers ruraux, réduit de façon significative la réintégration scolaire. Nous concluons que la réintégration scolaire après abandonné de l'école est faible dans la province du Nord-Ouest, laquelle appelle à des programmes visant à agir sur les facteurs qui entravent la réintégration l'école des jeunes filles.

Mots clé: réinsertion scolaire; l'abandon; la grossesse; les quartiers; la structure familiale de l'école

\footnotetext{
* Corresponding Author

475
} 


\section{Introduction}

School dropout, especially of women is prevalent in most sub-Saharan African countries and is responsible for slowing the achievement of MDG 2 on universal primary education and completion of secondary education for most women in this region. Despite a policy on school reintegration, especially due to pregnancy, being in place in many countries, the proportion of women who previously dropped out of school and re-enter schooling continue to be low (Mwansa 20II).

The paper used the theory of social disorganization to explain the low rate of school reentry. The theory was originally developed by Shaw and Mckay (1942) to explain spatial differentials in crime rates. They observed that crime rates are higher in neighbourhoods where the institutions of social control such as the family, schools, churches and community groups are weak thereby reducing social capital and collective efficacy to prevent crime (Sampson et al. 1997). Family structures also influence crime rates in such a way that disrupted families experience higher crime rates because such families lack the control over the behaviour of their members (Sampson 1986). The theory has therefore been used to explain schooling outcomes by examining the effect of neighboushoods and family structures on school re-entry.

In this paper, neighbourhood has been defined in two ways. Firstly, as a virtual construct in which a network of connections characterized by shared beliefs, circumstances, relationships and concerns bind individuals to one another. The shared values and beliefs are based on race, ethnicity, religion or social class which enables members to promote a common agenda regardless of where they live (Chaskin 1997). Secondly, defined as a spatial construct, neighbourhoods are characterized by sharing residential areas (urban, informal settlements or rural) where households are in close proximity to one another (Melvin, 1985) and does not only project family identity, but also express cultural believes, practices and behaviour (Adebayejo \& Onyeonoru 2003). In this construct, people are differentiated by culture, economic status, lifestyle, facilities and leisure activities (Keller 1968), which can affect schooling outcomes including school reentry. On the other hand, family structures are grouped into four types including both parent, single parent mother headed, single parent father headed, and extended families (Derman-Sparks \& Edwards
2009), which have different effects on individual education outcomes.

\section{Literature Review:}

A number of previous studies have identified neighbourhoods as important in influencing individual life outcomes including schooling outcomes (Sampson et al. 2002), which can be impeded by school dropout through poor neighbourhood socioeconomic conditions. A previous study observed that neighbourhood economic and social differentiation undermine long term relations leading to weak social ties, which make women in poorer neighbourhoods who previously dropped out of school to prefer work to schooling (Ampiah \& Adu-Yeboah 2009). Neighbourhoods can also affect schooling outcomes through cultural diversity, which acts as a barrier for shared values (Madyun 20II). The clash in cultural and religious attitudes towards the school re-entry of girls who previously dropped out of school due to pregnancy is particularly important in this regard. A previous study by Chigona \& Chetty (2008) noted that re-entry of teenage mothers to school is disapproved by some groups because teenage mothers are regarded as bad examples to other girls.

Neighbourhoods also impede school re-entry through the perceived or actual school participation of neighbourhood peers because peers are critical in instituting appropriate attitudes and behaviors (Madyun 20II). For example, negative peer influence is strongly associated with low educational outcomes. A study by Fordham \& Ogbu (1986) among adolescents in the US found that most adolescents preferred popularity and acceptance in the peer group over schooling, suggesting that where peer perceptions are not supportive to good schooling outcomes, peers did not maximize opportunities that increased their schooling. A previous study by Harding (2003) also found that neighbourhoods influence schooling outcomes through age at sexual debut and teenage pregnancy, which is consistent with another study which found that teenagers in low socioeconomic neighbourhoods had sexual debut at a young age (Burgard \& Lee-Rife 2009; Adeboyejo \& Onyeonoru, 2003), become teenage mothers and dropout out of school (Crane 1991).

Regarding family structures, previous studies found that teenage girls in disrupted families are likely to experience school disruptions due to a 
number of factors including poor socioeconomic conditions faced by children in single parent mother headed and extended families (Campbell et al. 2010; Rwenge 2003), where discriminatory allocation of household resources for education due to poverty, reduces the chances of girls who previously dropped out of school to re-enter schooling. Early age at sexual debut, teenage pregnancy and school dropout (Burgard \& Lee-Rife 2009), and delinquent and criminal behaviour (Petrosino et al. 2009), are also common among girls in single parent and extended families which has been attributed to lack of parental authority, monitoring and supervision, which a previous study identified with school dropout (Macleod \& Tracy 20I0).

Although knowledge on school dropout and its predictors in South Africa appears to be prevalent, our understanding of school re-entry and its predictors in South Africa in general and North West province in particular is low. This calls for the estimation of school re-entry rate of women who previously dropped out of school and identify the significant predictors influencing school re-entry.

\section{Data and Methods}

\section{Data}

Cross-sectional data on 306 black women from two districts (Bojanala and Modiri-Molema) in the North West Province of South Africa collected in 2010 were used. The survey collected data on educational trajectories of women aged 22-40 years of age who were enrolled in school at age 14 and were never previously pregnant, but dropped out of school for any reason at any time and grade after age 14.

A multi-stage sampling design was used to select women for interview. The first stage involved selecting the districts of Bojanala and ModiriMolema out of the four districts of North West province by use of simple random sampling. In the second stage four local municipalities were selected by use of stratified random sampling using the urban and rural neighbourhoods as a stratification criterion. In the third stage, 600 households were selected through systematic sampling. From each household, one woman aged between 22 and 40 years was randomly selected for interview. This group of women were selected because they have all passed through adolescence, a period of emotional, psychological, physical and behavioural turbulence, during which they could have dropped out of school permanently or re-joined schooling and matriculated at grade 12 .

A structured and pre-coded questionnaire was used to collect data on selected individual, school, household and neighbourhood level characteristics of women from age 14 to the date of school dropout or school re-entry which ever occurred last. The questionnaire was translated into Setswana, the dominant language in the North West province and then back to English before data collection to ensure that the meanings of the translations remained consistent. However, 18 questionnaires were dropped from this analysis because of incomplete data. In this paper, data on 306 women who previously dropped out of school were analysed.

Ethical approval was obtained from the Higher Degrees and Research Committee of the Faculty of Human and Social Sciences of North-West University, Mafikeng Campus and permission to collect data from the respective study areas was obtained from the North West province Premiers office, district managers, ward councillors and chiefs. Informed and signed consent was obtained from each respondent after they were briefed on the objectives and processes of the study. Study subjects were assured of the confidentiality of their identity and data collected and were also informed of their right to participate or withdraw from the study at any stage without consequences.

\section{Variable measures}

School re-entry status was the dependent variable. It was measured as re-entered school at any time after school dropout for any reason (re-entrants) or never re-entered school after school dropout (non-reentrants). School re-entry status was coded "I" if a woman re-joined schooling and " 0 " if otherwise.

The independent variables comprised of individual, school, household and community level covariates. The individual level covariates were: age cohort which was categorized as $<30,30-34$ and 35 years or older; age at sexual debut categorized as $<18$ and 18 years or older; and school pregnancy status categorized as pregnant at school and never pregnant at school. School level covariates included reasons for school dropout which was categorized as pregnancy related and other reasons (financial, health, academic and lack of interest); age at school dropout was categorized $<17,17-19$ and 20 years or older; grade at school dropout was categorized < grade 8, grades 8-10 and grades $1 \mathrm{I}-12$; and 
duration of school dropout was categorized $<=1$, at least 2 years and 3 or more years.

Regarding household level covariates, mothers' highest grade attainment categorized as < grade 8, grades $8-10$ and grade $1 \mathrm{I}$ or higher, number of siblings categorized as "I", "2", " 3 " and " 4 " or more; and family structures categorized as both parent, single parent mother headed, single parent father headed and extended families, were analyzed. Community level covariates included in the analysis were: perceived schooling status of neighbourhood peers; district of neighbourhood residence; and type of place of neighbourhood residence categorized as rural and urban.

\section{Statistical analyses}

Data analysis was done at three stages by use of SPSS version 21. Descriptive statistics of women was performed to provide a profile of women who previously dropped out of school at the first stage and the results are presented as frequency distributions. The second stage estimated the rate of school re-entry and compared it by selected individual, school, household and neighbourhood level covariates. The Pearson's chi-square statistic was used to estimate the association between school re-entry status and the individual, school, household and neighbourhood level covariates at $95 \% \mathrm{Cl}$.

In the third stage, the nested binary logistic regression model was implemented (Elisa, 1992). Model I tested the hypotheses that "family structure and type of neighbourhood residence are significant and independent predictors of school re-entry." Model 2 tested the hypotheses that "family structure and neighbourhood residence remained significant and independent predictors of school re-entry" even after controlling for the effects of other individual, school, household and neighbourhood level covariates simultaneously. The variables included in the models were those that were significant at the bivariate analyses.

\section{Results \\ Profile of study population}

Overall, 306 women ever dropped out of school. Individual, school, household and neighbourhood data on the women are displayed in Table I. More than half of the women $(51 \%)$ were in the 22-30 years age group and the mean age of the women was 29.8 years. The mean age at sexual debut was 17.4 years and most women $(53 \%)$ had sexual debut at $<18$ years of age. The mean age at school pregnancy was 18.2 and nearly 6 out of 10 women experienced school pregnancy. However, only $39.2 \%$ of the women dropped out of school due to pregnancy related reasons and the majority $(60.8 \%)$ of the women dropped out of school due to other reasons (financial, health, academic and lack of interest). Table I also shows that the mean age at school dropout was 19.4 years and most women, nearly $45.5 \%, 29.7 \%$ and $24.8 \%$ dropped out of school at 17-19, under 17 and 20 or more years of age respectively; and the mean grade at school dropout was grade 9.8 . Nearly $48 \%$ and only $10 \%$ dropped out of school at grades 8-10 and <grade 8 respectively. The mean duration of school dropout was 2.2 years.

Distribution of women by household variables show that the mean grade attained by the mothers' of the women was grade 7.4 and nearly $47 \%$ followed by $40 \%$ and $13 \%$ attained < grade 8 , grade 8- I0 and grade II or higher respectively. The mean number of siblings was 3.6 and the majority of the women (46.4\%) had at least 4 siblings and only $16 \%$ had only one (I) sibling. Additionally, $35 \%, 40 \%$, $11.4 \%$ and $13.4 \%$ of the women were in both parents, single parent mother headed, single parent father headed and extended families respectively at school dropout. Nearly $57 \%$ and $43 \%$ of the women perceived their neighbourhood peers were not at school and at school respectively; $65 \%$ and $35 \%$ were in Bojanala and Modiri-Molema districts; and $62 \%$ and $38 \%$ were in rural and urban neighbourhoods respectively at school dropout. Only 86 women, representing $28 \%$ of the women who previously dropped out of school, re-entered school.

Table I Distribution of women who ever dropped out of school by selected individual, school, household and neighbourhood level characteristics

\begin{tabular}{lrr}
\hline Characteristics & $\%$ & Number \\
\hline Age cohort & & \\
$22-30$ & 50.7 & 155 \\
$30-34$ & 26.1 & 80
\end{tabular}




\begin{tabular}{|c|c|c|}
\hline 35 years or older & 23.2 & 71 \\
\hline Mean age & 29.8 & 306 \\
\hline \multicolumn{3}{|l|}{ Age at first sex } \\
\hline Less than 18 & 52.9 & 162 \\
\hline 18 years or older & 47.1 & 144 \\
\hline Mean age & 17.4 & 306 \\
\hline \multicolumn{3}{|l|}{ School pregnancy status } \\
\hline Yes & 58.2 & 178 \\
\hline No & 41.8 & 128 \\
\hline Mean age at first pregnancy & 18.2 & 306 \\
\hline \multicolumn{3}{|c|}{ Reasons for dropping out of school } \\
\hline Pregnancy related & 39.2 & 120 \\
\hline Others & 60.8 & 186 \\
\hline \multicolumn{3}{|l|}{ Age at school dropout } \\
\hline Less than 17 & 29.7 & 88 \\
\hline $17-19$ & 45.5 & 121 \\
\hline $20+$ & 24.8 & 97 \\
\hline Mean age & 19.4 & 306 \\
\hline \multicolumn{3}{|l|}{ Grade at school dropout } \\
\hline Less than grade 8 & 10.1 & 31 \\
\hline Grades 8-10 & 47.7 & 146 \\
\hline Grades II-12 & 42.2 & 129 \\
\hline Mean grade & 9.8 & 306 \\
\hline \multicolumn{3}{|l|}{ Duration of school dropout } \\
\hline 1 & 33.7 & 103 \\
\hline 2 & 32.7 & 100 \\
\hline 3 years or higher & 33.7 & 103 \\
\hline Mean duration & 2.2 & 306 \\
\hline \multicolumn{3}{|l|}{ Mothers level of education } \\
\hline Less than grade 8 & 46.7 & 143 \\
\hline Grades 8-10 & 39.9 & 122 \\
\hline Grade II or higher & 13.4 & 41 \\
\hline Mean grade & 7.4 & 306 \\
\hline \multicolumn{3}{|c|}{ Number of siblings in the household } \\
\hline 1 & 15.7 & 48 \\
\hline 2 & 20.9 & 64 \\
\hline 3 & 17.0 & 52 \\
\hline 4 or higher & 46.4 & 142 \\
\hline Mean siblings & 3.6 & 306 \\
\hline \multicolumn{3}{|l|}{ Family structure } \\
\hline Both parents & 39.5 & $12 \mid$ \\
\hline Single parent mother headed & 30.7 & 94 \\
\hline Single parent father headed & 17.3 & 53 \\
\hline Extended & 12.4 & 38 \\
\hline \multicolumn{3}{|c|}{ Perceived schooling status of peers } \\
\hline Peers are not schooling & 57.2 & 175 \\
\hline Peers are schooling & 42.8 & $13 \mid$ \\
\hline \multicolumn{3}{|c|}{ District of residence at school dropout } \\
\hline Bojanala & 64.7 & 198 \\
\hline Modiri-Molema & 35.3 & 108 \\
\hline \multicolumn{3}{|l|}{ Type of place of residence } \\
\hline Rural & 61.8 & 189 \\
\hline Urban & 38.2 & 117 \\
\hline \multicolumn{3}{|l|}{ School re-entry status } \\
\hline Returned to school & 28.1 & 86 \\
\hline Did not return to school & 71.9 & 220 \\
\hline Total & 100.0 & 306 \\
\hline
\end{tabular}

\section{Correlates of school re-entry}

In Table 2 the school re-entry status of women who previously dropped out of school are presented by 479 selected individual, school, household and neighbourhood level covariates. School re-entrants increased from $18.7 \%$ in the $22-30$ years age cohort to $38 \%$ in the 35 
years or older age cohort. Slightly higher than $44 \%$ of the women who become pregnant at school re-entered schooling compared to only $5.5 \%$ of the women who did not become pregnant at school. Additionally, nearly $57 \%$ of the women who dropped out of school due to pregnancy re-entered schools compared to only $9.7 \%$ of women who dropped out of school for other reasons.

School re-entrants decreased with increase in age at school dropout and duration of school dropout. About $45 \%$ of school re-entrants dropped out of school at $<17$ years of age compared to only 13.2\% who dropped out of school at 20 years or older respectively; and $52.4 \%$ compared to only II\% who dropped out of school for at least one (I) year and three (3) or more years respectively.

Table 2 also shows that the majority of school reentrants were in extended families (44.7\%) followed by
$34 \%$ and $24.5 \%$ in both parent and single parent father headed families respectively. Only $16 \%$ of school reentrants were from single parent mother headed families. Additionally, $37.2 \%$ of school re-entrants perceived their neighbourhood peers were in school compared to $24.6 \%$ who perceived that their neighbourhood peers were not in school; nearly $22.2 \%$ were in Modiri-Molema compared to $40.4 \%$ in Bojanala; and $21.2 \%$ were in rural compared to nearly $36.8 \%$ in urban neighbourhoods. The bivariate results show that age cohort, school pregnancy status, reasons for school dropout, age at school dropout, duration of school dropout, family structure, perceived schooling status of neighbourhood peers, district and type of neighbourhood residence were significantly associated with school re-entry status at $\mathrm{p}<0.05$.

Table 2 Percentage distributions of women by school re-entry status and selected individual, school, household and neighbourhood level characteristics

\begin{tabular}{|c|c|c|c|c|}
\hline \multirow[t]{2}{*}{ Characteristics } & \multicolumn{3}{|c|}{ School re-entry status } & \multirow[t]{2}{*}{ Total } \\
\hline & Yes & No & $\mathbf{X}_{2}$ & \\
\hline \multicolumn{5}{|l|}{ Age cohort } \\
\hline Less than 30 & $18.7(29)$ & $81.3(126)$ & $13.75 * * *$ & $100.0(155)$ \\
\hline $30-34$ & $37.5(30)$ & $62.5(50)$ & & $100.0(80)$ \\
\hline 35 years or older & $38.0(27)$ & $62.0(44)$ & & $100.0(7 I)$ \\
\hline \multicolumn{5}{|l|}{ Age at first sex } \\
\hline Less than 18 years & $3 \mathrm{I} .5(5 \mathrm{I})$ & $68.5(111)$ & 1.94 & $100.0(162)$ \\
\hline 18 years or older & $24.3(35)$ & $75.7(109)$ & & $100.0(144)$ \\
\hline \multicolumn{5}{|c|}{ Ever been pregnant at school } \\
\hline Yes & $44.4(79)$ & $55.6(99)$ & $55.80 * * * *$ & $100.0(178)$ \\
\hline No & $5.5(7)$ & $94.5(121)$ & & $100.0(128)$ \\
\hline \multicolumn{5}{|c|}{ Reasons for dropping out of school } \\
\hline Pregnancy related & $56.7(68)$ & $43.3(52)$ & $79.7 \mid * * * * *$ & $100.0(120)$ \\
\hline Others & $9.7(18)$ & $90.3(168)$ & & $100.0(186)$ \\
\hline \multicolumn{5}{|c|}{ Age at school dropout } \\
\hline Less than 17 years & $45.1(4 I)$ & $54.9(55)$ & $21.93 * * * * *$ & $100.0(91)$ \\
\hline $17-19$ & $25.2(35)$ & $74.8(104)$ & & $100.0(139)$ \\
\hline 20 years or older & $13.2(10)$ & $86.8(66)$ & & $100.0(76)$ \\
\hline \multicolumn{5}{|c|}{ Grade at school dropout } \\
\hline Less than grade 8 & $29.0(9)$ & $71.0(22)$ & 0.11 & $100.0(31)$ \\
\hline Grades 8-10 & $28.8(42)$ & $71.2(104)$ & & $100.0(148)$ \\
\hline Grades II-12 & $27.1(35)$ & $71.9(220)$ & & $100.0(129)$ \\
\hline \multicolumn{5}{|c|}{ Duration of school dropout } \\
\hline 1 & $52.4(54)$ & $47.6(49)$ & $48.13 * * * * *$ & $100.0(103)$ \\
\hline 2 & $21.0(2 I)$ & $79.0(79)$ & & $100.0(100)$ \\
\hline 3 years or higher & $10.7(11)$ & $89.3(92)$ & & $100.0(103)$ \\
\hline \multicolumn{5}{|c|}{ Mothers level of education } \\
\hline Less than grade 8 & $25.9(37)$ & $74.1(106)$ & 0.69 & $100.0(143)$ \\
\hline Grades 8-10 & $30.3(37)$ & $69.7(85)$ & & $100.0(122)$ \\
\hline Grade II or higher & $29.3(12)$ & $70.7(29)$ & & $100.0(4 I)$ \\
\hline \multicolumn{5}{|c|}{ Number of siblings in the household } \\
\hline 1 & $31.3(15)$ & $68.7(33)$ & 2.36 & $100.0(48)$ \\
\hline 2 & $34.4(22)$ & $65.6(42)$ & & $100.0(64)$ \\
\hline 3 & $26.9(14)$ & $73.1(38)$ & & $100.0(52)$ \\
\hline 4 or higher & $24.6(35)$ & $75.4(107)$ & & $100.0(142)$ \\
\hline
\end{tabular}




\section{Family structure}

Both parent

Single parent mother headed

Single parent father headed

Extended

Perceived schooling status of peers

Peers are not schooling

Peers are schooling

District of residence at school dropout

Bojanala

Modiri-Molema

\section{Type of place of residence}

Rural

Urban

Total

$\begin{array}{ll}33.9(41) & 66.1(80) \\ 16.0(15) & 84.0(79) \\ 24.5(13) & 75.5(40) \\ 44.7(17) & 55.3(21)\end{array}$

$24.6(43)$

$32.8(43)$

75.4 (132)

67.2 (88)

4.60*

| $4.40 * * *$

$100.0(121)$

$100.0(94)$

$100.0(53)$

$100.0(38)$

$40.4(80)$

$22.2(24)$

$59.6(118)$

77.8 (84)

13.19*****

100.0 (198)

100.0 (108)

30.9 (77)

15.8 (9)

69.1 (172)

$84.2(48)$

$6.69 * * *$

$100.0(249)$

$100.0(57)$

100.0 (306)

Level of significance ${ }^{*} \mathrm{p}<0.05$; ** $\mathrm{p}<0.0 \mathrm{I}$; *** $\mathrm{p}<0.00$ I; **** $\mathrm{p}<0.000$ I

\section{Predictors of school re-entry}

The multivariate results predicting school re-entry of women are presented in Table 3 by use of two models. Model I presents the results on the hypothesis that "family structure is a significant predictor of school re-entry" and "district and type of place of neighbourhood residence are significant predictors of school re-entry." The results show that bpth parent and extended family structures significantly increased school re-entry by 2.83 $(p<0.00 \mathrm{I})$ and $4.56(p<0.00 \mathrm{I})$ times respectively; and residing in Bojanala district significantly increased school re-entry by $2.14(\mathrm{p}<0.05)$ times respectively. Conversely, residing in a rural neighbourhood significantly reduced school re-entry by $59 \%(\mathrm{p}<0.00 \mathrm{I})$.

Model 2 presents the results of the hypotheses that "family structure remained a significant predictor of school re-entry "and district and type of place of neighbourhood residence remained significant predictors of school re-entry" after controlling for the effects of other individual, school, household and neighbourhood level covariates simultaneously. The results show that although the effects of family structure was reduced, it remained a significant predictor of school re-entry and both parent and extended families significantly increased school re-entry by $2.32(p<0.0 \mathrm{I})$ and $2.92(\mathrm{p}<0.0 \mathrm{I})$ times respectively; and residing in Bojanala district remained significant and increased school re-entry by $2.53(\mathrm{p}<0.00 \mathrm{I})$ times. Another covariate that significantly increased school re-entry was age cohorts, showing that belonging to the 22-30 year age cohort significantly increased school re-entry by $4.33(p<0.00 \mathrm{l})$ times compared to the older age cohort ( $>=30$ years). Conversely, living in a rural neighbourhood significantly reduced school re-entry by $44 \%(p<0.05)$. Other covariates that reduced school re-entry were dropping out of school due to pregnancy $(62 \%, p<0.000 \mathrm{I})$, dropping out of school at $17-19(60 \%, p<0.000 \mathrm{I})$ and 20 years of age or older $(40 \%, p<0.0 \mathrm{I})$ and the perception that neighbourhood peers were not in school also significantly reduced school re-entry by $56 \%$ $(\mathrm{p}<0.05)$.

Table 3 Binary logistic regression results showing the Odds of returning to school for women who previously dropped out of school

\begin{tabular}{llccccc}
\hline Selected characteristics & \multicolumn{3}{c}{ Model I } & \multicolumn{2}{c}{ Model 2 } \\
\cline { 2 - 6 } & SE & OR & Cl & SE & OR & Cl \\
Reasons for dropping out of & & & & & \\
school & & & & 0.389 & $0.38^{* * * * *}$ & $0.07-0.43$ \\
$\begin{array}{l}\text { Pregnancy } \\
\text { Other }{ }^{8}\end{array}$ & & & & & 1.00 & \\
\hline
\end{tabular}




\begin{tabular}{|c|c|c|c|c|c|c|}
\hline \multicolumn{7}{|l|}{ Age cohort } \\
\hline $22-30 \AA$ & & & & 0.433 & $4.33^{* * * *}$ & $1.85-10.13$ \\
\hline $30-34$ & & & & 0.483 & 1.44 & $0.58-3.57$ \\
\hline 35 years or older ${ }^{\circledR}$ & & & & & 1.00 & \\
\hline \multicolumn{7}{|c|}{ Age at school dropout } \\
\hline Less than 17 years & & & & & 1.00 & \\
\hline $18-19$ & & & & 0.561 & $0.40 * * * *$ & $0.02-0.22$ \\
\hline 20 years or older ${ }^{\circledR}$ & & & & 0.508 & $0.60 * *$ & $0.25-1.07$ \\
\hline \multicolumn{7}{|l|}{ Family structure } \\
\hline Both parents & 0.350 & $2.83 * * *$ & $\mid .42-5.61$ & 0.434 & $2.32 * *$ & $\mathrm{I} .42-5.6 \mathrm{I}$ \\
\hline Single mother ${ }^{\circledR}$ & & 1.00 & & & 1.00 & \\
\hline Single father & 0.438 & $1.47 *$ & $0.62-3.46$ & 0.553 & 1.06 & $0.36-3.14$ \\
\hline Extended & 0.468 & 4.56 *** & $1.89-10.98$ & 0.542 & $2.92 * *$ & $\mathrm{I} .0 \mathrm{I}-8.45$ \\
\hline \multicolumn{7}{|c|}{$\begin{array}{l}\text { Perceived schooling status of } \\
\text { peers }\end{array}$} \\
\hline Not in school ${ }^{\circledR}$ & & & & 0.359 & $0.44 *$ & $0.22-0.88$ \\
\hline In school & & & & & 1.00 & \\
\hline \multicolumn{7}{|c|}{$\begin{array}{l}\text { District of residence at } \\
\text { dropout of school }\end{array}$} \\
\hline Bojanala ${ }^{\circledR}$ & 0.410 & $2.14^{*}$ & $0.96-4.78$ & 0.360 & $2.53 * * *$ & $1.25-5.12$ \\
\hline Modiri-Molema ${ }^{\circledR}$ & & 1.00 & & & 1.00 & \\
\hline \multicolumn{7}{|c|}{$\begin{array}{l}\text { Place of residence at school } \\
\text { drop out }\end{array}$} \\
\hline Urban & & & & & 1.00 & \\
\hline Rural ${ }^{\circledR}$ & 0.278 & $0.4 I^{* * * *}$ & $1.18-3.59$ & 0.548 & $0.56 *$ & $0.19-4.63$ \\
\hline Constant & 0.508 & $0.78 *$ & & 0.817 & $6.46 *$ & \\
\hline
\end{tabular}

\section{Discussion}

Despite a policy on school reintegration, especially due to pregnancy, being in place in many countries in sub-Saharan Africa, the proportion of women who previously dropped out of school and re-join schooling to complete their education continue to be low. This has significantly reduced the overall educational attainment of women. The low school re-entry rate is a concern mainly because the proportion of girls who drop out of school is large, and has a much wider ramification on overall development, especially the attainment of most MDGs associated with education and childbearing, in countries affected by high school dropout rate of the girl child. South Africa is one of the countries with a high school dropout rate for the girl child, mostly due to school pregnancy. This paper therefore estimated the school re-entry rate of girls/women who previously dropped out of school for any reason and identified the significant predictors affecting school re-entry.

The paper found that despite a policy on school reintegration being in place in South Africa, overall, the school re-entry rate, at only $28.1 \%$, was low in this study population. Although the paper identified some covariates that significantly increased school re-entry, including belonging to the youngest age cohort and living in both parent and extended families, there are other covariates, including dropping out of school due to pregnancy, dropping out of school at ages 17-19, perceiving that neighbourhood peers were not in school and residing in rural neighbourhoods, which significantly reduced school re-entry. This is worrying as pregnancy, which mostly occurs at 17-19 years, is the most common cause of school dropout for girls in South Africa.

School pregnancy and dropping out of school due to pregnancy is the most important individual and school level covariate undermining school reintegration of the girl child. This finding is consistent with previous studies (Chihona \& Chetty 2008) which identified lack of support from teachers; lack of counseling to combat stigma due to teenage pregnancy, poor teacher and peer attitudes towards teenage mothers (Varga 2003), poor parental attitude due to stigma of teenage pregnancy and poor socioeconomic status of families of teenage mothers as the main reasons for low school re-entry of previously pregnant girls. Cultural norms against premarital pregnancy and the perception that teen mothers are bad moral and role models for other girls also contribute to the low school re-entry 
of girls who dropped out of school due to pregnancy.

Other reasons for low school re-entry of teenage mothers include lack of aspirations on the part of the teenage mothers, poverty, child care demands and lack of appropriate and reliable child care support (Dench et al. 2007). A previous study revealed that the responsibility of looking after their children is one of the most important factors impeding the reentry of teenage mothers into school (Sodi 2009). The above situation reveals that low school re-entry for previously pregnant girls are due to lack of social capital at the school, household and neighbourhood levels.

Although literature on the effects of schooling status of neighbourhood peers is inadequate, our finding that the perception that neighbourhood peers are not in school significantly reduced the reentry of teenage mothers in school is not surprising. This is because in many communities dropping out of school due to pregnancy was supported to protect other girls from becoming pregnant and as a result, most girls who drop out of school due to pregnancy were barred from schooling, creating the perception that schooling is over for girls who become pregnant at school and therefore do not return to complete their education (Chigona \& Chetty 2008). Additionally, school dropout precedes pregnancy for many girls, implying that girls, who perceive that their neighbourhood peers are not in school, also perceive that they have nothing or little to lose by not returning to school after dropout, which is an indication that peers are an important influencing factor through the so-called reflective problem (Lazear 200I). A study by Vitaro et al. (200I) on negative social experiences and school dropout appear to support the suggestion that out of school neighbourhood peers do encourage teenage school dropouts not to return to school.

The finding that residing in Bojanala significantly increased school reintegration of women who previously dropped out of school is expected and is attributed to the historical advantages resulting from a combination of factors including its urbanity, the role of the mining conglomerates and tourism which contributed to better social infrastructure including schools and lower poverty levels than in ModiriMolema. The study sites in Bojanala as a neighbourhood system therefore have better social capital structures that contributed to better schooling outcomes including the reintegration of girls back to school. For example, the availability of more schools also means that the distance to schools is not only shorter and makes girls feel safer, but also enables girls who previously dropped out of school to change schools thereby avoiding the stigma from peers and teachers (Chigona \& Chetty 2008); and the higher incomes from the mining, tourism and service sector employments could have made money available to return girls to school, which factor a previous study found increased school reintegration of the girl child (Hunt 2008).

Our results also show that compared to urban areas, school reintegration of teenage mothers is low in rural areas, which could be affected by the fewer alternative schools in rural areas. This is in part due to the stigma girls who previously became pregnant at school face, mostly from their peers, necessitating them to change schools. The finding is also consistent with the urban-rural differentials in participation in education, which has been observed to be lower in rural neighbourhoods (Birdsall et al. 2005), which was attributed to poverty in rural household, and fewer and inaccessible schools in rural neighbourhoods (Hunt 2008).

However, the results did not support the view that urban neighbourhoods reduce school reintegration of the girl child because of the pressures to work and contribute to family income, availability of jobs and higher poverty rates in urban poor neighbourhoods (Tinto 2006). The finding also does not support the view that weaker social capital in urban neighbourhoods, where the high degree of social economic and cultural differentiation impedes social cohesion, does not appear to impede school reintegration of the girl child. Instead, rural neighbourhoods where there exists a strong network of relatives and friends held together by shared values and norms (culture) which is expected to exact stronger social, psychological and financial support, appears to impede school reintegration of the girl child.

Furthermore, the finding that both parent families significantly increased school reintegration of girls is encouraging and consistent with a previous study, which observed that the both parent family contributes more to better education outcomes than any other family structure (Sun \& Li 20II), which was attributed to the socioeconomic stability and closer supervision and support associated with both parent families. However, the finding that the 
extended family significantly increased school reintegration of the girl child was a surprise, as the level of care and support in this family system is expected to be lower and not conducive for schooling because most children in the extended family in South Africa are looked after by aging less resourceful grandparents. Nevertheless, it is likely that the schooling needs of girls in extended families are provided by their either one or both absentee biological parents, who are absent so as to engage in employment.

The extended family is also an important safety net especially for orphans and vulnerable children, and in this regard is a vital social capital capable of buffering schooling inequalities. A previous study (Lloyd 1994) supported the assertion that the extended family is an important social capital for mitigating schooling inequalities, and this was found to be particularly important for HIV/AIDS orphans and vulnerable children (Mishra \& Bignami-Van 2008; Ainsworth et al. 2005), which is prevalent in North West province of South Africa.

Despite the above findings, this study could have been affected by some limitations. Firstly, lack of data on the school time socioeconomic situation of the women impeded the estimation of the impacts of socioeconomic status on school dropout and school re-entry. Secondly, the results could have been affected by the accuracy of reporting data on some of the events, notably pregnancy and childbirth, which are usually affected by social desirability biases, which was more likely if the pregnancy was aborted. Thirdly, most of the events that are associated with school dropout and re-entry which happened a long time ago could have been forgotten or inaccurately reported. Fourthly, the small sample size of 306 women who previously dropped out of school could have affected the estimation of the effects of some of the variables and affected the generalizability of the results. Nevertheless, the paper has identified some of the significant predictors of the low rate of school reintegration for the girl child who previously dropped out of school, which is important for formulating strategies for school reintegration of girls and women.

\section{Conclusion}

This study concludes that although the prevalence of school dropout was high in the study population, the rate of school re-entry of girls was low in the North West province of South Africa. This calls for stronger measures aimed at increasing reintegration of teenage women into schools if the objective of increasing education outcomes for women is to be achieved. In doing so a broader approach including individual, school, household and neighbourhood level issues that impede school reintegration of the girl child after school dropped out should be adopted.

\section{Acknowledgement}

The authors are grateful to the School of Research and Graduate Studies at North-West University Mafikeng Campus for the financial support towards collecting the data used in this study. We also extend our gratitude to all the women who provided the data used in this paper and the research assistants who collected the data.

\section{References}

Adeboyejo, T \& Onyeonoru, I 2003. "Aspects of home environment and adolescent sexual behaviour in South Western Nigeria." African Population Studies 20, ( I):45-52.

Ampiah, G \& Adu-Yeboah, C 2009. "Mapping the incidence of school dropouts: A case study of communities in Northern Ghana." Comparative Education 45, (2):219-232.

Ainsworth, M., Beegle, K \& Koda, G 2005. "The impact of adult mortality and parental deaths on primary schooling in North-Western Tanzania." The Journal of Development Studies 4I, (3): 4I2439.

Birdsall, N., Levine, R \& Ibrahim, A 2005. "Towards universal primary education: investments, incentives, and institutions." European Journal of Education 40, (3):337-349.

Burgard, S \& Lee-Rife, S 2009. "Community characteristics, sexual initiation, and condom use among young black South Africans." Journal of Health and Social Behavior 50:293-309.

Campbell, P., Handa, S., Moroni, M., Odongo, S \& Palermo, T 2010. "Assessing the 'orphan effect' in determining development outcomes for children in II Eastern and Southern African countries." Vulnerable Children and Youth Studies 5, (I): 12-32.

Chaskin, R.J 1997. "Perspectives on neighbourhood and community: Review of the literature." Social Service Review 72, (4):52I-547.

Chigona, A \& Chetty, R 2008. "Teen mothers and schooling: lacunae and challenges." South African Journal of Education 28:26I-28I 
Crane, J 199I. "The epidemic theory of ghettos and neighbourhood effects on dropping out and teenage childbearing." American Journal of Sociology 96: 1226-1 259.

Dench, S., Bellis, A \& Tuohy, S (2007). Young mothers not in learning: A qualitative study of barriers and attitudes. Report 439, Institute for Employment Studies.

Derman-Sparks, L \& Edwards, L.O (2009). Anti-bias education for young children and ourselves. Washington, DC: National Association for the Education of Young Children.

Elisa, T.L \& Wang, J (1992). Statistical methods for survival data analyses. 2nd ed. New York, NY: John Willy \& Sons, Inc.

Fordham, S \& Ogbu, J 1986. “Black students' school success: Coping with the burden of 'acting white." Urban Review 18: I 76-206.

Hallman, K \& Grant, M (2004). Poverty, educational attainment, and livelihoods: how well do young people fare in KwaZulu-Natal, South Africa? Washington, D.C.: Population Council.

Harding, D.J 2003. "Counterfactual models of neighbourhood effects: The effect of neighbourhood poverty on dropping out and teenage pregnancy." American Journal of Sociology 109, (3):676-719.

Hunt, $H$ (2008). Dropping out from school: A crosscountry review of literature. Research Monograph No 16. Create Pathways to access.

Keller, S (1968). The Urban neighbourhood: A sociological perspective. New York: Random House.

Lazear, E 200I. “Education production.” Quarterly Journal of Economics II6, (3):777-803.

Lloyd, C.B (1994). Fertility, family size, and structure: Consequences for families and children. New York: The Population Council.

Macleod, C.I \& Tracey, T 2010. "A decade later: follow-up review of South African research on the consequences of and contributory factors in teen-aged pregnancy." South African Journal of Psychology 40, (I): 18-31.

Madyun, M 20II. "Connecting social disorganization theory to African-American outcomes to explain the achievement gap." Educational Foundations 25, (3-4):2I-35.

Melvin, P.M 1985. "Changing contexts: Neighbourhood definition and urban organization.” American Quarterly 37, (3):357367.

Mishra, V \& Bignami-Van, S.A (2008). Orphans and Vulnerable Children in high HIV prevalence countries in Sub-Saharan Africa. DHS Analytical Studies No. 15. Calverton, Maryland, USA: Macro International Inc.

Mwansa, A (20II). Re-entry tom school after giving birth: An evaluation of the process used to design and implement policy in Zambia. Create pathways to access: Research Monograph No. 70.

Petrosino, A., Derzon, J \& Lavenberg, J 2009. “The role of family in crime and delinquency: evidence from prior quantitative reviews." Southwest Journal of Criminal Justice 6, (2): 108-132.

Rwenge, M 2003. "Poverty and sexual risk behaviour among young people in Bamenda, Cameroon." African Population Studies 18, (I):91- 104.

Sampson, R.J 1986. Neighbourhood family structure and the risk of personal victimization. In R.J. Sampson and J.M Byrne (Eds.), The Social Ecology of Crime, Springer-Verlag, New York, pp. 25-46).

Sampson, R.J., Raudenbush, S.W \& Earls, F 1997. "Neighbourhoods and violent crime: A multilevel study of collective efficacy." Science 227: 916-924.

Sampson, R.J., Morenoff, J.D \& Gannon-Rowley, T 2002. "Assessing 'neighbourhood effects': Social processes and new directions in research." Annual Review of Sociology 28:443-478.

Shaw, C \& McKay, H.D (1942): Juvenile delinquency and urban areas. Chicago: University of Chicago Press.

Sodi, E.E (2009). Psychological impact of teenage pregnancy on pregnant teenagers. Polokwane, South Africa. Master of Education dissertation, University of Limpopo.

Sun, Y \& Li, Y 20I I. "Effects of family structure type and stability on children"s academic performance trajectories." Journal of Marriage and Family 73, (3):54I-556.

Tinto, V 2006. "Research and practice of student retention: What next?" Journal of Collage Student Retention 8, (I): I-19.

Varga, C.A 2003. "How gender roles influence sexual and reproductive health among South African adolescents." Studies in Family Planning 34: $160-172$. 
African Population Studies, Vol. 28, No. I, April 2014

Vitaro, F., Larocque, D., Janos, M \& Trembay, R.E

out of school." Educational Psychology 21, ( 200I. "Negative social experiences and dropping 4):402-4I5. 